\title{
Asthma symptoms improvement in moderate persistent asthma patients with gastroesophageal reflux disease (GERD): the role of proton-pump inhibitor
}

Agus Dwi Susanto ${ }^{1}$, Faisal Yunus ${ }^{1}$, Wiwien Heru Wiyono ${ }^{1}$, Neni Sawitri ${ }^{1}$, Syafruddin AR Lelosutan ${ }^{2}$

\begin{abstract}
Abstrak
Penelitian ini untuk mengevaluasi efek obat penghambat pompa proton (esomeprazol), penggunaan bronkodilator inhaler dan arus puncak ekspirasi (APE) pada pasien asma persisten sedang dengan penyakit refluks gastroesofagus (PRGE). Penelitian ini adalah uji klinis terbuka dengan kontrol di RS Persahabatan Jakarta dari Juli 2004 sampai Oktober 2005. Diagnosis PRGE ditegakkan jika ditemukan gejala PRGE dan gambaran esofagitis pada endoskopi dan atau pada pemeriksaan histopatologi hasil biopsi esofagus. Pada fase 1 (periode run in) selama 2 minggu, pasien mendapat pengobatan budesonid inhalasi dosis $2 x 200$ ug/ hari. Pada fase 2, pasien diacak menjadi 2 kelompok dan mendapat pengobatan budesonid inhalasi dosis 2 x 400 ug/hari dengan esomeprazol $40 \mathrm{mg} / \mathrm{hari}$ atau tanpa esomeprazol (kelompok kontrol) selama 8 minggu. Fase 3 (periode wash out) pasien mendapat pengobatan budesonid inhalasi dosis $2 \times 200$ ug/hari. Catatan harian dilakukan pada periode run in, setelah pengobatan 4 minggu, 8 minggu dan periode wash out. Sebanyak 32 pasien (23 perempuan dan 9 laki-laki) menyelesaikan penelitian ini. Rata-rata skor gejala asma total harian berkurang secara bermakna pada kelompok esomeprazol dibanding tanpa esomeprazol setelah pengobatan 8 minggu (-2,29vs -0,90; $p<0,05)$. Rata-rata penggunaan bronkodilator inhaler berkurang secara bermakna pada kelompok esomeprazol dibanding tanpa esomeprazol setelah pengobatan 8 minggu $(-1,09$ vs - 0,42; $p<0,05)$. Nilai APE pagi dan sore meningkat lebih besar pada kelompok esomeprazol dibanding tanpa esomeprazol tetapi tidak berbeda bermakna. Disimpulkan bahwa pemberian esomeprazol $40 \mathrm{mg}$ perhari memperbaiki gejala asma dan penggunaan bronkodilator inhalasi pada asma persisten sedang dengan PRGE. (Med J Indones 2008; 17: 169-74)
\end{abstract}

\begin{abstract}
This study aimed to evaluate effect of proton pump inhibitor (esomeprazole) on asthma symptoms, use of inhaled bronchodilator and peak expiratory flow rate (PEFR) in moderate persistent asthma with gastroesofageal refluks disease (GERD). This randomized single blind, controlled clinical trial study was conducted at Persahabatan Hospital, Jakarta from July 2004 until October 2005. Samples were moderate persistent asthma patients with GERD. GERD is diagnosed GERD symptoms and proof of oesophagitis from endoscopy and or histapatologic examination from oesophagus biopsy. Phase 1:2 week run-in period patient received inhaled budesonide 2x200 ug/day. Phase 2: patient randomised to receive inhaled budesonide $2 \times 400 \mathrm{ug} /$ day with esomeprazole $40 \mathrm{mg} /$ day or without esomeprazole (control group) for 8 weeks. Phase 3: 4 week wash out period, patient receive inhaled budesonide 2 $x 200 \mathrm{ug} /$ day. Diary cards were assessed at run-in periode, after treatment 4 weeks, 8 weeks and wash out. There were 32 patients (23 female and 9 male) completed the study. Mean total asthma symptoms score daily were significantly decreased on esomeprazole $v s$ without esomeprazole after 8 weeks $(-2.29$ vs $-0.90 ; p<0.05)$. Mean use of inhaled bronchodilator was significantly decreased on esomeprazole vs without esomeprazole after 8 weeks (-1.09vs -0.42; $p<0.05$ ). Morning and evening PEFR improved higher on esomeprazole than without esomeprazol but were not significantly difference. In conclusion, administration esomeprazole 40 mg daily improved asthma symptoms and lower the use of inhaled bronchodilator in moderate persistent asthma patients with GERD. (Med J Indones 2008; 17: 169-74)
\end{abstract}

Keywords: Asthma symptoms, inhaled bronchodilator, moderate persistent asthma, GERD, esomeprazole

\footnotetext{
${ }^{1}$ Department of Pulmonology and Respiratory Medicine, Faculty of Medicine University of Indonesia, Persahabatan Hospital, Jakarta, Indonesia

2 Department of Internal Medicine, Gatot Subroto Central Army Hospital, Jakarta, Indonesia
}

Asthma symptoms could be induced by any triggers include gastroesophageal reflux. ${ }^{1}$ Gatroesophageal reflux disease (GERD) is symptoms and/or oesophageal mucosal disruptions (oesophagitis) due to abnormal reflux of gaster acid and material into oesophagus. ${ }^{2}$ 
Gastroesophageal reflux is closely associated with many symptoms and disorders of airways including chronic cough and asthma. ${ }^{3,4}$

Several studies showed that approximately $45-77 \%$ asthma patients had GERD symptoms. ${ }^{5,6}$ Endoscopic findings from asthma patients showed that oesophagitis prevalence in asthma patients approximately $27-43 \%{ }^{4,7} \mathrm{~A}$ study with $24 \mathrm{~h} \mathrm{pH}$ monitor found abnormal acid reflux in $33-90 \%$ asthma patients. ${ }^{6.8}$ There were several factors in pathogenesis gastroesophageal reflux in asthma patients. Among others, there were autonomic dysregulation, increased pressured gradient between the thorax and the abdominal cavity, diaphragma cruralis dysfunction, hiatus hernia and used of asthma medications. Furthermore, gastroesophageal reflux induced bronchoconstriction in asthma patients by esophago-bronchial vagal reflex, increased bronchial reactivity and acid microaspiration into airways. ${ }^{6,910}$ Another mechanism that may play a role is neurogenic inflammation (axon reflex) with tachykinin and $\mathrm{P}$ substance release in the airways. ${ }^{6,10}$

Management of GERD in asthma patients should be considered seriously to obtain optimal control of asthma. The role of GERD treatment in asthma control is still unclear. Antireflux medications did not show consistent result improving lung function, asthma symptoms, reducing night asthma or use of asthma medications in asthma patients. ${ }^{1,9,11} \mathrm{~A}$ review by Bowrey et.al ${ }^{9}$ stated several studies with antireflux treatment decreased asthma symptoms, decreased asthma medications but had minimal effect on lung function. The use of proton pump inhibitor (PPI) as drug of choice for GERD showed a better result than other antireflux drugs. ${ }^{2,6,9}$ This study aimed to evaluate the effect of the latest generation proton pump inhibitor (esomeprazole) to reduce asthma symptoms, use of inhaled bronchodilator and increase peak expiratory flow rate (PEFR) in moderate persistent asthma with GERD.

\section{METHODS}

This study was a randomized single blind controlled clinical trial in moderate persistent asthma patients with GERD symptoms in Asthma Clinic at Persahabatan Hospital, Jakarta, Indonesia, from July 2004 until October 2005. Inclusion criterias was moderate persistent asthma patients (GINA 2002), age 15-65 years old, postbronchodilator reversibility test $\geq 12 \%$, bronchial provocations test must be positive. ${ }^{12}$ There were one or more typical GERD symptoms include heartburn, regurgitation, atypical chest pain, dysphagia or water brash., ${ }^{2,13}$ Oesophagitis was established by endoscopic examination, classified using Los Angeles 1994 classifications, ${ }^{13}$ or histopatologycal examination from oesophageal biopsy. Patients underwent the procedure of endoscopy at subdivision endoscopy Department of Internal Medicine Gatot Subroto Army Hospital, Jakarta, Indonesia. Histopatologic examination from oesophageal biopsy was performed at the Department of Anatomic Pathology at Persahabatan Hospital-Jakarta.

Patients were divided into 2 groups, the first group received esomeprazole treatment and the other without esomeprazole (control group). In each group was given standard treatment of moderate persistent asthma, which is budesonide inhalation $2 \times 400 \mu \mathrm{g} /$ day as a controller and salbutamol $100 \mu \mathrm{g} /$ puff as a reliever. In each group the conservative treatment of GERD was given such as lifestyle modifications and antacid (if necessary).

Duration of study was 14 weeks, divided into 2 weeks run in periode, 8 weeks treatment periode and 4 weeks wash out periode. In each periode there was daily evaluation for asthma symptoms, use of inhaled bronchodilator ( $\beta_{2}$ agonist inhaled short acting), morning and evening PEFR and weekly evaluation for GERD symptoms. Scoring for asthma symptoms were cough, night sleep disturbance, activity disturbance and wheezing.

Asthma symptom total score is the total value of asthma symptoms score in one day. Scoring for GERD symptom is evaluated by diary card, through symptoms e.g. heartburn, atypical chest pain and regurgitation. GERD symptom total score is the total value of GERD symptoms score in one weeks. Statistical Program for Social Sciences (SPSS) 10 was used for data analysis. Parametric test is use if normally data distribution with multiple repeated measured analysis of variance (Anova) test to test variable by time of treatment (before, during, and after treatment) and comparison between the two groups. Nonparametric test is used if data distribution is abnormal. Friedmann test for test variable by time of treatment and Mann Whitney test or $t$ test to evaluate comparative variable between the two groups at the same time, i.e. cough score, sleep disturbance etc.

Because the result is concluded from 2 tests, therefore significant statistic test used Bonnferoni correction. Differentiation between 2 qualitative data proportion 
used chi-square test. In parametric test value $P<0.05$ is considered significantly different; and nonparametric test value $\mathrm{P}<0.003125$ is considered significantly different.

This study has been approved by Ethics Committee of the Faculty of Medicine University of Indonesia.

\section{RESULTS}

Out of 36 patients, four patients dropped out from this study: 2 patients from esomeprazole group (one patients resign and one patient with melena); and in control group 2 patients who did not continue after 4 weeks treatment, and one patients exacerbate that needed systemic corticosteroid. Therefore, a number of 32 patients moderate persistent asthma with GERD were finished this study, 16 patients in each group.

In esomeprazole group and control group (without esomeprazole) were similarly distributed in term of gender, age, height, body weight, history of asthma illness, lung function ( $\left.\mathrm{FEV}_{1} \%, \mathrm{FVC} \%, \mathrm{PEFR}\right)$, and bronchial hyperreactivity $\left(\mathrm{PC}_{20}\right)$. However, baseline value of $\mathrm{VC}$ was different between two groups. Vital capacity (VC) in control group was higher than esomeprazole group. GERD symptoms before treatment between 2 groups were similarly distributed (Table 1).

Among the 32 patients most of them (53.1\%) had erosive oesophagitis. Erosive oesophagitis divide into grade A 11 (34.4\%) patients, grade B 4 (12.5\%) patients and grade C $2(6.3 \%)$ patients. Oesophageal biopsy was performed in $30(93.75 \%)$ patients. Histopathological examination result concluded oesophagitis in $28(87.5 \%)$ patients and not representative in $2(5.6 \%)$ patients. Oesophagitis were found in esomeprazole group in 13 $(81.25 \%)$ patients and control group in $15(93.75 \%)$ patients. Endoscopyandhistopathologycal examinations between two groups were similarly distributed.

From Table 2 and Figure 1, administration of esomeprazole showed improvement of asthma symptoms after 8 weeks treatment $(-2.29$ vs $-0.90 ; \mathrm{p}<0.05)$. Total score of GERD symptoms were decreased in esomeprazole group compared to control but showed no significant difference (12.67 vs $-8.19 ; \mathrm{p}>0.003125)$. Mean use of inhaled bronchodilator was significantly decreased on esomeprazole vs control after 8 weeks $(\mathrm{P}<0.05)$. Morning PEFR value after 8 weeks in esomeprazole group were increased $30.2 \mathrm{~L} /$ minute. The result was

Table 1. Several characteristics of patients

\begin{tabular}{|c|c|c|c|}
\hline & $\begin{array}{c}\text { Esomeprazole } \\
(n=16)\end{array}$ & $\begin{array}{l}\text { Control } \\
(n=16)\end{array}$ & $\mathrm{P}$ \\
\hline \multicolumn{4}{|l|}{ Gender } \\
\hline Male & $4(25 \%)$ & $5(31.25 \%)$ & 0.125 \\
\hline Female & $12(75 \%)$ & $11(68.75 \%)$ & \\
\hline Age (years) & $42.69(11.11)$ & $37.88(11.01)$ & 0.228 \\
\hline Height (cm) & $155.25(6.83)$ & $157.69(7.48)$ & 0.343 \\
\hline Body weight (kg) & $59.75(13.18)$ & $60(12.08)$ & 0.956 \\
\hline History of asthma illness (years) & $22.44(14.59)$ & $22.19(12.59)$ & 0.959 \\
\hline \multicolumn{4}{|l|}{$\begin{array}{l}\text { Lung function and bronchial } \\
\text { hyperreactivity }\end{array}$} \\
\hline $\mathrm{VC}(\mathrm{ml})$ & 2225 (408.7) & $2583.8(579.7)$ & 0.052 \\
\hline $\mathrm{FVC} \%$ prediction & $76.2(11.3)$ & $80.9(11.6)$ & 0.429 \\
\hline $\mathrm{FEV}_{1}$ & $1586.9(286.3)$ & $1691.9(391.8)$ & 0.394 \\
\hline $\mathrm{FEV}_{1} \%$ prediction & $72.9(6.7)$ & $71.2(7.7)$ & 0.794 \\
\hline PEFR (L/mnt) & $258.8(33.2)$ & $269.5(76.4)$ & 0.613 \\
\hline $\mathrm{PC}_{20}(\mathrm{mg} / \mathrm{ml})$ & $0.17(0.3)$ & $0.08(0.09)$ & 0.954 \\
\hline \multicolumn{4}{|l|}{ GERD symptoms } \\
\hline Heartburn & $11(68.8 \%)$ & $14(87.5 \%)$ & 0.200 \\
\hline Atypical chest pain & $13(81.3 \%)$ & $12(75 \%)$ & 0.669 \\
\hline Regurgitation & $16(100 \%)$ & $16(100 \%)$ & 1.000 \\
\hline Dysphagia & $2(12.5 \%)$ & $4(25 \%)$ & 0.365 \\
\hline Water brash & $6(37.5 \%)$ & $6(37.5 \%)$ & 1.00 \\
\hline
\end{tabular}


higher compare to control group PEFR value, which was $5.9 \mathrm{~L} /$ minute. Night PEFR after 8 weeks in esomeprazole group was increased $26.8 \mathrm{~L} /$ minute higher than control group 9.2 L/minute. Comparison morning and night PEFR between two groups after 8 weeks treatment were not significantly difference $(p>$ $0.003125)$.

\section{DISCUSSION}

Characteristic of patients showed that asthma patients with GERD symptoms mostly female. This result was similar with previous study by Tug et.al. ${ }^{14}$ However it was different from studies by Roussos et.al ${ }^{5}$, Talib et.al, ${ }^{15} \mathrm{Hsu}$ et.al ${ }^{16}$, and previous study about asthma prevalence in East Jakarta. ${ }^{17}$ Age mean for esomeprazole

Table 2. Treatment result after 4 weeks, 8 weeks treatment, and wash out

\begin{tabular}{|c|c|c|c|c|c|}
\hline & Baseline & $\begin{array}{c}\text { After } 4 \text { weeks } \\
\text { treatment }\end{array}$ & $\begin{array}{c}\text { After } 8 \text { weeks } \\
\text { treatment }\end{array}$ & Wash out & \multirow[t]{2}{*}{$\mathrm{P}$} \\
\hline & Mean (SD) & Mean(SD) & Mean (SD) & Mean (SD) & \\
\hline Asthma symptoms score* & $3.36(1.92)$ & $2.11(1.47)$ & $1.07(0.81)$ & $0.65(0.97)$ & $0.036^{\dagger}$ \\
\hline Asthma symptoms score & $3.49(1.22)$ & $2.92(1.76)$ & $2.59(1.76)$ & $2.01(1.47)$ & \\
\hline GERD symptoms score* & $17.34(8.63)$ & $7.91(7.18)$ & $5.66(7.26)$ & $4.67(7.38)$ & $0.045^{+}$ \\
\hline GERD symptoms score§ & $16.88(8.34)$ & $10.65(9.37)$ & $11.62(8.7)$ & $8.69(7.30)$ & \\
\hline Use of inhaled bronchodilator * & $1.51(1.24)$ & $0.73(0.66)$ & $0.42(0.47)$ & $0.65(0.95)$ & 0.003 \\
\hline Use of inhaled bronchodilator $§$ & $1.82(1.08)$ & $1.39(0.94)$ & $1.41(1.21)$ & $1.55(1.34)$ & \\
\hline Morning PEFR* & $252.7(71.3)$ & $274.2(68.6)$ & $282.9(65.6)$ & $278.3(70.2)$ & $0.016^{+}$ \\
\hline Morning PEFR ${ }^{\S}$ & $269.7(81.9)$ & $274.3(86.7)$ & $275.6(87.6)$ & $275.7(84.5)$ & \\
\hline Night PEFR* & $256.9(65.6)$ & $272.3(69.9)$ & $283.7(65.9)$ & $280.6(71.7)$ & 0.134 \\
\hline Night PEFR ${ }^{\S}$ & $272.7(80.7)$ & $282.5(90.2)$ & $280.6(71.7)$ & $284(82.61)$ & \\
\hline
\end{tabular}

Remarks:

$\mathrm{SD}=$ standard of deviation

* Patients who received esomeprazole $40 \mathrm{mg}$ /day

$\S$ Patients who did not received esomeprazole (control group)

$\dagger$ Anova test, P value after 8 weeks treatment

Mann Whitney test, $p$ value after 8 weeks treatment

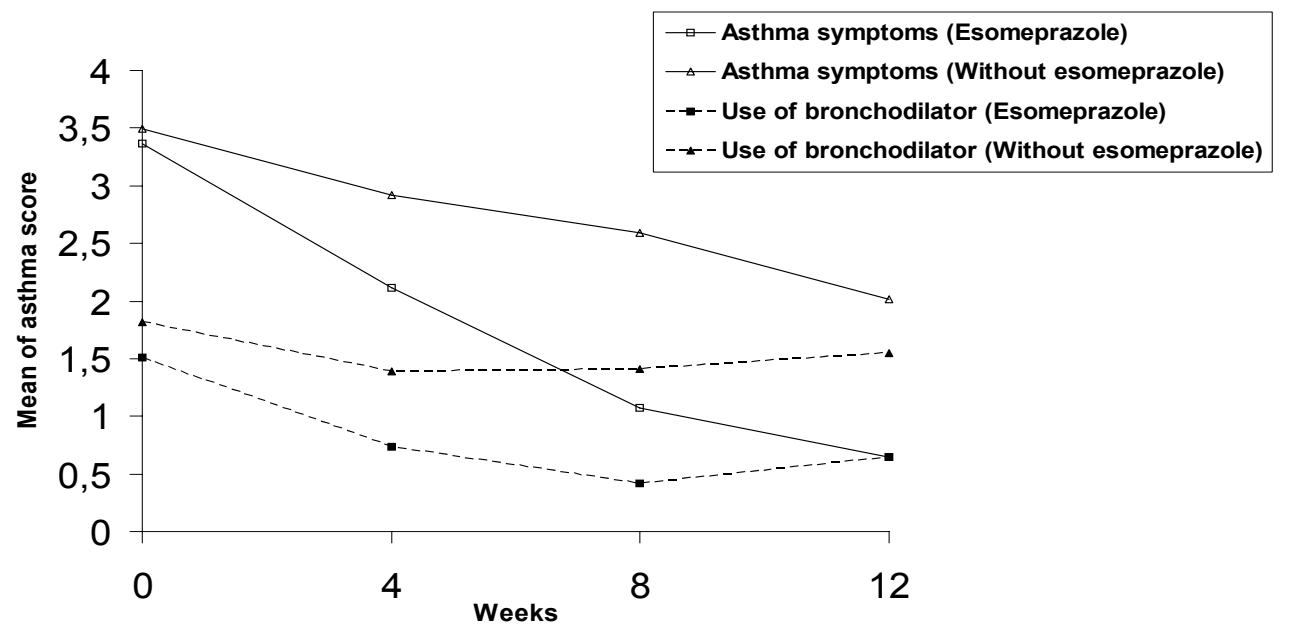

Figure 1. Asthma symptoms score and use of inhaled bronchodilator improvement between two groups 
administration was not different with other study - Roussos et al..$^{5}\left(42.9 \pm 14.2\right.$ year) also Talib et al. ${ }^{15}$ $(43.43 \pm 14.6$ year). Baseline of lung function (not include VC) and bronchial hiperreactivity was equally distributed between two groups. The value support the diagnosis moderate persistent asthma in all patients that finished this study. GERD symptoms in asthma patients were not different with previous study by Roussos et $\mathrm{al}^{5}$ and Nakase et al. ${ }^{7}$

Our study showed that asthma patients with GERD symptoms proven to have had erosive oesophagitis was likely in accordance with Talib et $\mathrm{al}^{15}$ which found $63.33 \%$ had erosive oesophagitis. Our result was higher than previous report that showed approximately 15$43 \% .{ }^{4,7}$ Our result was different from several previous studies because our patients were limited to asthma patients with GERD symptoms, however the other studies consisted of all asthma patients.

Total score of GERD symptoms in esomeprazole group decreased higher than control in each periode. In control group also improved GERD symptoms maybe caused patients still received conservative treatment for GERD. Conservative treatment alone for GERD could decreased reflux symptoms in asthma patients with GERD. ${ }^{9}$

In this study, GERD treatment with esomeprazole improved asthma symptoms. This result was likely similar with the other findings ${ }^{6}$ that agrresive medical therapy improved asthma symptoms in about $70 \%$ of asthmatic with GERD. In addition, our study revealed that total score of asthma symptoms were decreased $68.2 \%$ compared to baseline. This result was similar with study by Sharma ${ }^{18}$ which used omeprazole $40 \mathrm{mg} /$ daily for 8 weeks, found that daily asthma symptoms decreased significant. Moreover, Kiljander et.al ${ }^{19}$ found improvement only in nighttime asthma symptoms with omeprazole $40 \mathrm{mg} /$ daily. Previous studies using antisecretoy e.g. omeprazole did not consistently improve asthma symptoms. ${ }^{11}$ Inferior result maybe caused by inadequate reflux control. A review by Bowrey et.al concluded that a success with medical treatment were likely to be related directly to eliminate reflux. The conflicting findings of antisecretory therapy may be due to the inadequate control gastroesophageal reflux. ${ }^{8}$ Esomeprazole is newer generation of PPI drugs. Pharmacodinamic study result esomeprazole had activity acid suppresion higher than omeprazole..$^{20}$ On the other hand, esomeprazole $40 \mathrm{mg}$ /day showed controlled intragastric $\mathrm{pH}$ more than $4(\mathrm{pH}>4)$ better and longer than omeprazole $20 \mathrm{mg} /$ day. ${ }^{21}$

The use of inhaled bronchodilator was significantly decreased compared to control. Several studies using antisecretory did not reduce the use of asthma medications. Several previous studies showed medical antireflux treatment could decrease use of asthma medications, However, other studies show contrary result. ${ }^{11}$ Asthma symptoms in patients who received esomeprazole were decreased. This may cause decrease use of asthma medications (inhaled bronchodilator). Inhaled bronchodilator is a reliever in asthma medications on necessary basis that act quickly to relieve asthma symptoms. ${ }^{22}$

Morning and night PEFR improvement in esomeprazole group was higher than control. Most studies about role of antireflux treatment on asthma patients previously showed that antireflux treatment had minimal or no effect on PEFR. ${ }^{6,9,11}$ A limited improvement of daily PEFR were found in several other studies. Tsugeno et al. $^{23}$ found PEFR improvement in only $38.1 \%$ of asthma patients with GERD. Nakase et al. ${ }^{7}$ reported that improvement of morning PEFR and night PEFR were only in asthma patients who had erosive oesophagitis grade $\mathrm{C} / \mathrm{D}$. Kiljander et al. ${ }^{24}$ using esomeprazole $20 \mathrm{mg}$ twice daily showed improved PEFR only in asthma patients with GERD and nocturnal respiratory symptoms. There were several unknown factors contributed in successful improvement of PEFR.

\section{CONCLUSION}

Administration of esomeprazole $40 \mathrm{mg}$ /day for 8 weeks improved asthma symptoms and decreased the use of inhaled bronchodilator in moderate persistent asthma patient with GERD.

\section{Acknowledgements}

We thank Dr. Sabarinah Prasetyo (School of Public Health, University of Indonesia) for her technical assistance.

\section{REFERENCES}

1. National Heart, Lung and Blood Institute. Risk factors. In: Global Initiative for Asthma. Global strategy for asthma management and prevention. Bethesda: The Institute: 2002 . 
2. DeVault KR, Castell OD. Updated guidelines for the diagnosis and treatment of gastroesophageal reflux disease. Am J Gastroenterology. 1999;94:1434-42.

3. Gislason T, Janson C, Vermeire P, Plaschke P, Bjornsson E, Gislason D. et al. Respiratory symptoms and nocturnal gastroesophageal reflux. A population-based study of young adults in three european countries. Chest. 2002;121:158-63.

4. Lazenby JP, Harding SM. Chronic cough, asthma and gastroesophageal reflux. Curr Gastroenterol Report. 2000; 2:217-23.

5. RoussosA, Gerogianni I,LagogianniI, TsimpoukasF, Filippou $\mathrm{N}$, Eliopoulos I, et al. Prevalence of gastroesophageal reflux disease symptoms in bronchial asthma patients in Greece. Pneumon. 2003;16: 67-73.

6. Stein MR. Gastroesophageal reflux disease and asthma in the adult. Immunol Allergy Clin North Am. 2001;21:449-71.

7. Nakase H, Itani T, Mimura J, Kawasaki T, Komori H, Tomioka H, et al. Relationship between asthma and gastrooesophageal reflux: significance of endoscopic grade of reflux oesophagitis in adult asthmatics. J Gastroenterol \& Hepatol. 1999;14:715-22.

8. Harding SM, Schan CA, Richter JE. 24-h esophageal PH testing in asthmatics: respiratory symptom correlation with esophageal acid events. Chest. 1999;115:654-9.

9. Bowrey DJ, Peters JH, DeMeester TR. Gastroesophageal reflux disease in asthma. Effects of medical and surgical antireflux therapy on asthma control. Ann Surg. 2000; 231:161-72.

10. Harding SM. Gastroesophageal reflux, asthma and mechanisms of interaction. Am J Med. 2001; 111(suppl):812.

11. Coughlan JL, Gibson PG, Henry RL. Medical treatment for reflux oesophagitis does not consistenly improved asthma control: a systematic review. Thorax. 2001;56:198-204.

12. National Heart, Lung and Blood Institute. Diagnosis and classification. In: Global Initiative for Asthma. Global strategy for asthma management and prevention. Bethesda: The Institute:2002.

13. Dent J, Brunt J, Fendrick AM, Fennerty MB, Janssens J, Kahrilas PJ, et al. An evidence-based appraisal of reflux disease management-the Geneval Workshop Report. Gut. 1999;44 (supp12):S1-S16.
14. Tuğ T, Bahçecioglu H. The association between severity and stage of asthma symptoms in a distinctive period and gastroesophageal reflux. Turkish Respiratory J. 2003;4: 116-9.

15. Talib SH, Sane SD, Gopanpallikar AM, Kumbhakarna NR. Effect of Helicobacter pylori eradication theraphy in patients of bronchial asthma with gastroesophageal reflux disease (GERD). J Ind Ac Clin Med. 2003;4:39-49.

16. Hsu J, Lien H, Chang $\mathrm{C}$, Chen $\mathrm{G}$. Abnormal acid reflux in asthmatic patients in a region with low GERD prevalence. J Gastroenterol. 2005;40:11-5.

17. Yunus F, Antaria R, Rasmin M, Mangunegoro H, Jusuf A, Bachtiar A. Asthma prevalence among high school students in East Jakarta, 2001, based on ISAAC questionnaire. Med J Indones. 2003;12:178-86.

18. Sharma B, Daga MK, Kaushik M, Chhabra R, Azad M. Adult asthma and gastroesophageal reflux. The effect of omeprazole theraphy on asthma. Chest. 2003;124: 94S.

19. Kiljander TO, Salomaa EM, Hietanen EK, Terho EO. Gastroesophageal reflux in asthmatics. A double-blind, placebo-controlled crossover study with omeprazole. Chest. 1999;116:1257-64.

20. Zhao HL, Thomas GN, Leung WYS, Chen Q, Tomlinson B. Esomeprazole-a new proton pump inhibitor for the treatment of gastro-oesophageal reflux disease and peptic ulceration. Medical Progress. 2002;29:42-7.

21. Lind T, Rydberg L, Kyleback A. Esomeprazole provides improved acid control vs omeprazole in patients with symptoms of gastro-esophageal reflux disease. Aliment Pharmacol Ther. 2000;14:861-7.

22. GINA executive commitee. Asthma treatments. In: Global Initiative for asthma. Global strategy for asthma management. Ontario. Medical Communication Resource, Inc.; 2006.p.27-48.

23. Tsugeno H, Mizuno M, Fujiki S, Okada H, Okamoto M, Hosaki $\mathrm{Y}$, et al. A proton-pump inhibitor, rabeprazole. Improves ventilatory function in patients with asthma associated with gastroesophageal reflux. Scand J Gastroenterol. 2003;38:456-61.

24. Kiljander TO, Harding SM, Field SK, Stein MR, Nelson HS, Ekelund J, Illueca M, Beckman O, Sostek M. Effects of esomeprazole $40 \mathrm{mg}$ twice daily on asthma: a randomized placebo-controlled trial. Am J Respir Crit Care Med. 2006; 173:1091-7. 